Agustinus Purna Irawan, Indra Widjaja:

Implementation of Technology Acceptance Model to Evaluate Reliability of the New Student Selection Application Development

Implementasi Technology Acceptance Model Untuk Mengevaluasi Keandalan Pengembangan Aplikasi Komunikasi Seleksi Mahasiswa Baru

\title{
Implementation of Technology Acceptance Model to Evaluate Reliability of the New Student Selection Application Development
}

\section{Implementasi Technology Acceptance Model Untuk Mengevaluasi Keandalan Pengembangan Aplikasi Komunikasi Seleksi Mahasiswa Baru}

\author{
Agustinus Purna Irawan ${ }^{1,2}$, Indra Widjaja ${ }^{2}$ \\ ${ }^{1}$ Fakultas Teknik, Universitas Tarumanagara, Jl. Letjen S. Parman No. 1, Jakarta* \\ Email:agustinus@untar.ac.id \\ ${ }^{1,2}$ Program Studi Magister Manajemen, Universitas Tarumanagara, Jl. Letjen S. Parman No. 1, \\ Jakarta \\ Email: indraw@pps.untar.ac.id
}

Masuk tanggal : 18-10-2021, revisi tanggal : 14-11-2021, diterima untuk diterbitkan tanggal : 24-11-2021

\begin{abstract}
One of the important things in university management is the selection process for new students. Management of new student admissions needs to be planned, communicated, and implemented properly to obtain new students who meet the quantity and quality targets. The selection process for new students must follow the rules contained in Permendikbud No. 3 of 2020 concerning National Standards for Higher Education in Indonesia. This study aims to develop a model for evaluating the new student selection portal that has been developed at Tarumanagara University under the name Go Untar, where the implementation refers to Permendikbud No. 3 of 2020. Go Untar has been used as a communication portal and selection of prospective new students since 2020. The method used in this study refers to the TAM (Technology Acceptance Model) model developed by Davis, 1985 and combined with the Unified Theory of Acceptance and Use of Technology model (UTAUT) by Venkatesh et.al., 2003, to obtain a combination model to evaluate Go Untar. The results shows that the TAM API 2021 model, which was developed from the modification of the two TAM models above, can be used to analyze the effectiveness and convenience of Go Untar in the selection process for new students at Tarumanagara University. The results of the model application to evaluate Go Untar application show that Go Untar application is useful for registering new students quickly and effectively, as well as able to see accurate selection results. Go Untar is easily accessible and can be used properly as a medium of communication and selection of new students, starting from account creation, data entry process, selection, and real time selection results. Go Untar is effective in facilitating digital communication between prospective new students and administrators. The results of this study will be a reference in further development.
\end{abstract}

Keywords: Go Untar application, student registration, TAM model

\begin{abstract}
Abstrak
Salah satu hal penting dalam pengelolaan perguruan tinggi adalah proses penerimaan mahasiswa baru. Pengelolaan penerimaan mahasiswa baru perlu direncanakan, dikomunikasikan dan dilaksanakan dengan baik, sehingga memperoleh mahasiswa baru
\end{abstract}


yang memenuhi target kuantitas dan kualitas. Proses seleksi mahasiswa baru harus mengikuti aturan yang ada dalam Permendikbud No. 3 Tahun 2020 tentang Standar Nasional Pendidikan Tinggi di Indonesia. Penelitian ini bertujuan untuk mengembangkan model untuk mengevaluasi portal seleksi mahasiswa baru yang telah dikembangkan di Universitas Tarumanagara dengan nama Go Untar, dimana implementasinya merujuk pada Permendikbud No. 3 Tahun 2020. Go Untar telah digunakan sebagai portal komunikasi dan seleksi calon mahasiswa baru sejak tahun 2020. Metode yang digunakan dalam penelitian ini merujuk pada Model TAM (Technology Acceptance Model) yang dikembangkan oleh Davis, 1985 dan dikombainasikan dengan model Unified Theory of Acceptance and Use of Technology (UTAUT) oleh Venkatesh et.al., 2003, sehingga diperoleh model kombinasi untuk mengevaluasi Go Untar. Berdasarkan hasil penelitian yang telah dilakukan dapat disimpulkan bahwa Model TAM API 2021 yang dikembangkan dari modifikasi dua model TAM di atas, dapat digunakan untuk menganalisis keefektifan dan kemudahana Go Untar dalam proses seleksi mahasiswa baru di Universitas Tarumanagara. Hasil aplikasi model yang telah dikembangkan untuk mengevaluasi aplikasi Go Untar menunjukan bahwa aplikasi Go Untar yang telah dikembangkan bermanfaat untuk melakukan registrasi dengan cepat, efektif, dan dapat melihat hasil yang akurat. Go Untar mudah diakses dan dapat digunakan dengan baik sebagai media komunikasi dan seleksi mahasiswa baru, mulai dari pembuatan akun, proses pengisian data, seleksi dan hasil seleksi yang real time. Hal ini sangat bermanfaat bagi calon mahasiswa baru dan admin untuk berkomunikasi secara digital. Hasil penelitian ini akan menjadi referensi dalam pengembangan selanjutnya.

Kata Kunci: aplikasi Go Untar, pendaftaran mahasiswa, model TAM

\section{Pendahuluan}

Komunikasi dan proses penerimaan mahasiswa baru merupakan hal yang sangat penting dalam pengelolaan perguruan tinggi, khususnya Perguruan Tinggi Swasta (PTS). Hal ini terkait kemampuan PTS dalam mendapatkan pembiayaan yang utama untuk operasional kegiatan Tridharma Perguruan Tinggi berasal dari uang kuliah mahasiswa. Makin banyak mahasiswa yang dapat direkrut, maka perguruan tinggi dapat memperoleh dana yang dihimpun dari mahasiswa lebih banyak (Dyatmika, 2018).Di sisi lain, persaingan yang makin ketat antar perguruan tinggi untuk mendapatkan mahasiswa. Hal ini tentu saja mendorong perguruan tinggi untuk terus melakukan inovasi dalam proses penerimaan mahasiswa baru, termasuk di dalamnya dengan memanfaatkan berbagai platform media sosial dan media digital lainnya yang mudah diakses oleh calon mahasiswa (Harjadi \& Fatmasari, 2017).

Seperti yang dilakukan banyak perusahaan dimana proses komunikasi, pemasaran dan pelayanan pelanggan, telah menggunakan teknologi digital yang modern dan menyentuh banyak orang, maka perguruan tinggi juga tidak boleh tertinggal dalam menggunakan komunikasi dan pemasaran berbasis teknologi infomasi dan komunikasi yang sesuai dengan trend saat ini. Komunikasi yang intens dengan calon mahasiswa baru, orang tua dan semua pemangku kepentingan, sangat diperlukan untuk membangun kepercayaan masyarakat dan mitra. (Ongvongphaiboon \& Chantamas, 2021). 
Agustinus Purna Irawan, Indra Widjaja:

Implementation of Technology Acceptance Model to Evaluate Reliability of the New Student Selection Application Development

Implementasi Technology Acceptance Model Untuk Mengevaluasi Keandalan Pengembangan Aplikasi Komunikasi Seleksi Mahasiswa Baru

Secara umum, proses penerimaan mahasiswa baru di suatu perguruan tinggi di Indonesia harus mengacu pada Permendikbud No. 3 Tahun 2020 tentang Standar Nasional Pendidikan Tinggi. Pada Permendikbud No. 3 Tahun 2020 pasal 11 ayat (1) disebutkan bahwa karakteristik proses pembelajaran sebagaimana dimaksud dalam Pasal 10 ayat (2) huruf a terdiri atas sifat interaktif, holistik, integratif, saintifik, kontekstual, tematik, efektif, kolaboratif, dan berpusat pada mahasiswa. Selanjutnya pada ayat (10) berpusat pada mahasiswa sebagaimana dimaksud pada ayat (1) menyatakan bahwa capaian pembelajaran lulusan diraih melalui proses pembelajaran yang mengutamakan pengembangan kreativitas, kapasitas, kepribadian, dan kebutuhan mahasiswa, serta mengembangkan kemandirian dalam mencari dan menemukan pengetahuan. Berdasarkan pasal tersebut, perlu dipersiapkan proses seleksi mahasiswa baru yang dapat menunjang proses pembelajaran sehingga mencapai kepenuhan Standar Kompetensi Lulusan yang ditetapkan oleh masing-masing Perguruan Tinggi. (Peratuaran Menteri Pendidikam Dan Kebudayaan Republik Indonesia Nomor 3 Tahun 2020, 2020)

Pembiayaan yang diperlukan oleh masing-masing PTS berbeda-beda, tergantung dari wilayah, kebutuhan pembelajaran sesuai keunggulan yang ingin dicapai, kompetensi yang ingin dicapai, peningkatan kegiatan tri dharma lainnya yang juga sangat penting serta reputasi yang ingin dicapai. Sebagian PTS hanya mengandalkan biaya yang dikumpulkan dari para mahasiswanya, namun demikian ada juga PTS yang mengusahakan pendapatan lain-lain untuk mendukung pelaksanaan kegiatan pembelajaran dan kegiatan tridharma lainnya.

Proses penerimaan mahasiswa baru membutuhkan suatu cara dan sistem yang memudahkan calon mahasiswa mengakses PTS. Disisi lain, proses yang disiapkan harus mampu untuk melakukan proses seleksi yang baik, sehingga input calon mahasiswa dapat diseleksi dengan baik sesuai kriteria seleksi yang telah ditetapkan. Pengelolaan seleksi mahasiswa baru yang kredibel, transparan, mudah dilakukan dan menghasilkan calon mahasiswa baru yang sesuai dengan kriteria, perlu didesain dengan baik dan friendly bagi calon mahasiswa baru maupun pengelola penerimaan mahasiswa baru dan program studi.

Sejak tahun 2020, Universitas Tarumanagara telah mengembangkan aplikasi Go Untar sebagai portal seleksi mahasiswa baru. Go Untar dapat di akses melalui www.go.untar.ac.id atau melalui website Universitas Tarumanagara www.untar.ac.id. Aplikasi Go Untar telah menjadi portal utama dalam proses seleksi mahasiswa baru dan menjadi media komunikasi digital secara real time bagi calon mahasiswa baru dan pengelola adminisi di Universitas Tarumanagara. Calon mahasiswa mengakses aplikasi Go Untar untuk mendaftar dan mendapatkan berbagai informasi terkait dengan proses seleksi mahasiswa baru. Gambar 1 menunjukan aplikasi Go Untar dalam sistem teknologi informasi Universitas Taruamanagara. 


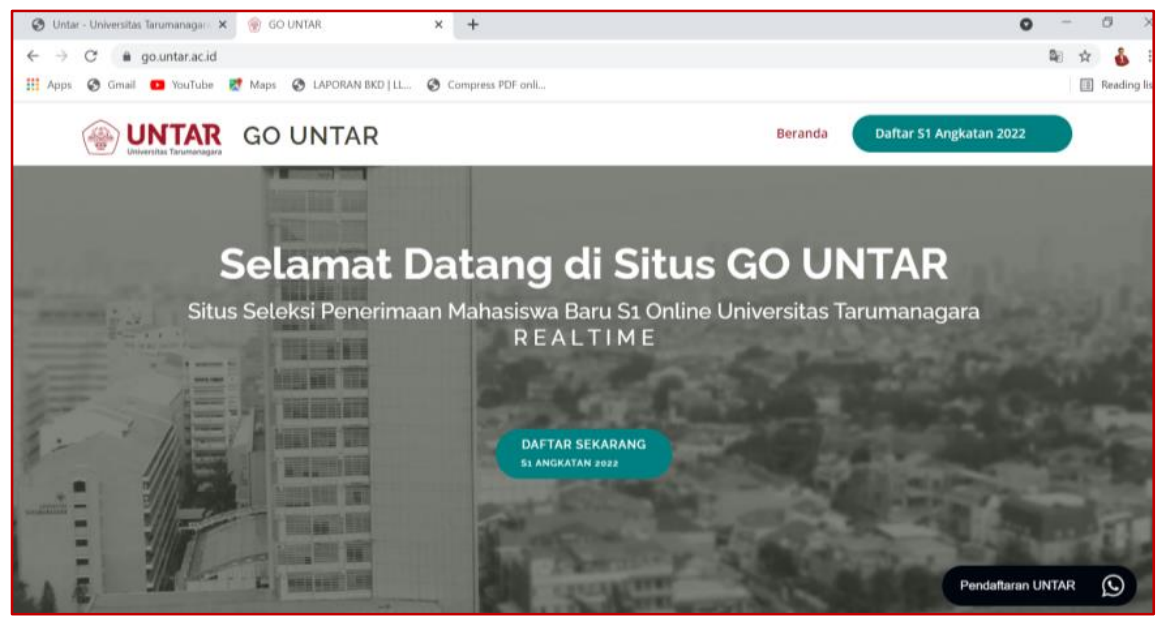

Gambar 1: Aplikasi Go Untar (Sumber: go.untar.ac.id)

Prinsip dasar dalam pengembangan portal Go Untar adalah bahwa calon mahasiswa harus dapat dengan mudah melakukan proses registrasi awal, melakukan proses seleksi dan menerima semua informasi terkait kelulusan seleksi serta informasi lanjutan seperti registrasi dan pembayaran uang kuliah.

Di dalam portal ini juga telah disiapkan pilihan program studi, semua dokumen pendukung yang harus diunggah dan persyaratan khusus lainnya sesuai dengan ketentuan di masing-masing program studi. Setelah mahasiswa melakukan seleksi secara daring, maka mahasiswa yang dinyatakan lulus sesuai dengan standar kelulusan minimal yang disiapkan oleh setiap program studi, maka calon mahasiswa tersebut memperoleh pemberitahuan dalam bentuk surat yang ditandatangani oleh rektor secara digital, apakah dinyatakan lulus atau tidak, yang dilengkapi dengan pemberitahuan biaya yang harus dibayar dan registrasi ulang dan persyaratan lain yang harus diunggah.

Permasalahan yang diangkat dalam penelitian ini menyangkut evaluasi keefektifan terhadap implementasi Go Untar sebagai portal utama dalam seleksi mahasiswa baru. Mengingat Go Untar menjadi satu-satunya portal dalam penerimaan mahasiswa baru di Universitas Tarumanagara untuk 15 program studi sarjana meliputi: Akuntansi Bisnis, Manajemen Bisnis, Hukum, Ilmu Komunikasi, Psikologi, Desain Interior, Desain Komunikasi Visual, Arsitektur, Perencanaan Wilayah dan Kota, Teknik Elektro, Teknik Industri, Teknik Mesin, Teknik Sipil, Sistem Informasi, Teknik Informatika, maka perlu dipastikan bahwa portal Go Untar dapat memenuhi kebutuhan calon mahasiswa dan pengelola penerimaan mahasiswa baru dan program studi, sehingga dapat menghasilkan jumlah mahasiswa terseleksi yang memenuhi target jumlah mahasiswa baru yang ditetapkan untuk setiap program studi. Perlu dikembangkan model evaluasi dan dilanjutkan dengan implementasi model tersebut, sehingga dapat dilihat apakah Go Untar telah menjadi aplikasi yang efektif dalam proses penerimaan mahasiswa baru.

Pengembangan model evaluasi aplikasi Go Untar, merujuk pada model yang digunakan untuk menunjukkan efektivitas adopsi pengguna terhadap teknologi baru. Salah satu model untuk mengukur kepuasan pengguna dalam 
Agustinus Purna Irawan, Indra Widjaja:

Implementation of Technology Acceptance Model to Evaluate Reliability of the New Student Selection Application Development

Implementasi Technology Acceptance Model Untuk Mengevaluasi Keandalan Pengembangan Aplikasi Komunikasi Seleksi Mahasiswa Baru

menggunakan teknologi baru adalah model TAM (Technology Acceptance Model). Model ini digunakan untuk mengidentifikasi faktor yang mempengaruhi pengguna untuk menerima teknologi baru (Chuttur, 2009), (Alharbi, 2014). Model TAM diperkenalkan pertama kali oleh Fred Davis pada tahun 1985 (Davis, 1985) yang mengembangkan dan menguji model teoritis pengaruh karakteristik sistem pada penerimaan pengguna sistem informasi berbasis komputer. Model TAM dikembangkan oleh Davis dengan dua tujuan, model ini dapat memberikan wawasan teoretis ke dalam desain dan implementasi yang sukses dari sistem Informasi. Kedua, TAM memberikan dasar praktis metodologi "pengujian penerimaan pengguna" yang memungkinkan perancang dan pelaksana sistem untuk mengevaluasi sistem baru yang diusulkan sebelum penerapan (Davis, 1985).

Model TAM mengemukakan bahwa niat perilaku individu untuk menggunakan teknologi informasi (TI) ditentukan oleh dua keyakinan (Davis, 1989), yaitu kegunaan yang dirasakan (perceived usefulness), yang didefinisikan sebagai sejauh mana seseorang percaya bahwa menggunakan TI akan meningkatkan kinerja pekerjaannya; dan persepsi kemudahan penggunaan (perceived ease of use), yang didefinisikan sebagai tingkat di mana seseorang percaya bahwa menggunakan TI akan bebas dari usaha.

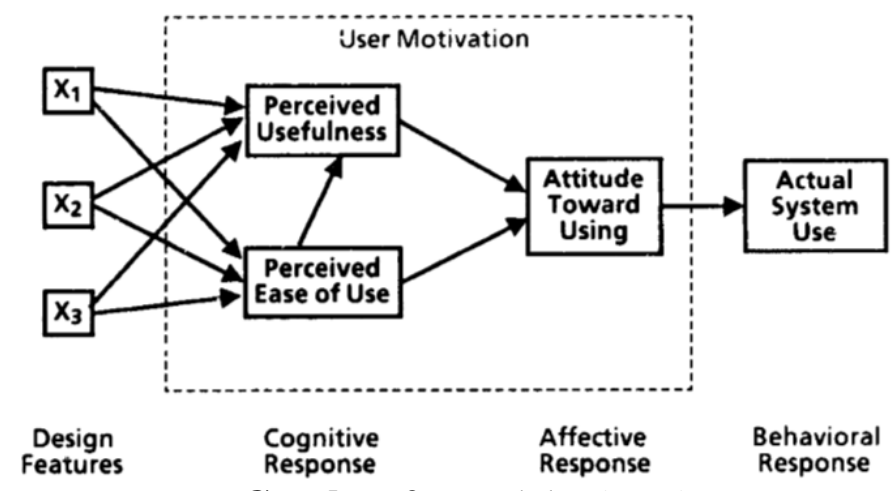

Gambar 2: Model TAM 1

(Sumber: Davis, 1985)

Model TAM mengalami pengembangan, Venkatesh dan Davis (2000) mengusulkan perluasan TAM yaitu Model TAM2 dengan mengidentifikasi tentang faktor yang menentukan perceived usefulness yaitu norma subjectif, image, relevansi pekerjaan, kualitas keluaran, dan hasil yang dapat didemonstrasikan. Venkatesh dan Davis (2000) menambahkan dua moderator pada model TAM2 yaitu, pengalaman dan kesukarelaan. TAM2 menyajikan dua proses teoretis pengaruh sosial dan proses kognitif untuk menjelaskan berbagai determinan perceived usefulness dan niat berperilaku (Intention to use) (Venkatesh \& Davis, 2000), yaitu pengaruh sosial dan proses kognitif. Sedangkan empat variabel, yaitu relevansi pekerjaan, kualitas luarant, hasil yang dapat didemonstrasikan, dan kemudahan penggunaan yang dirasakan (perceived ease of use) merupakan pengaruh kognitif pada perceived usefulness (kegunaan yang dirasakan). 
Model Unified Theory of Acceptance and Use of Technology (UTAUT) menggabungkan empat (4) faktor kunci dan empat (4) moderator yang terhubung untuk memprediksi niat perilaku untuk menggunakan teknologi yang digunakan dalam konteks organisasi (Venkatesh et al., 2003). UTAUT adalah alat yang lebih terperinci dan berguna bagi manajer sepenuhnya memahami faktor-faktor penerimaan teknologi, dan hambatan secara proaktif termasuk pelatihan, pemasaran, dan sebagainya. Facilitating condition didefinisikan sebagai derajat di mana seorang individu percaya bahwa infrastruktur organisasi dan teknis tersedia/ada untuk mendukung penggunaan sistem.

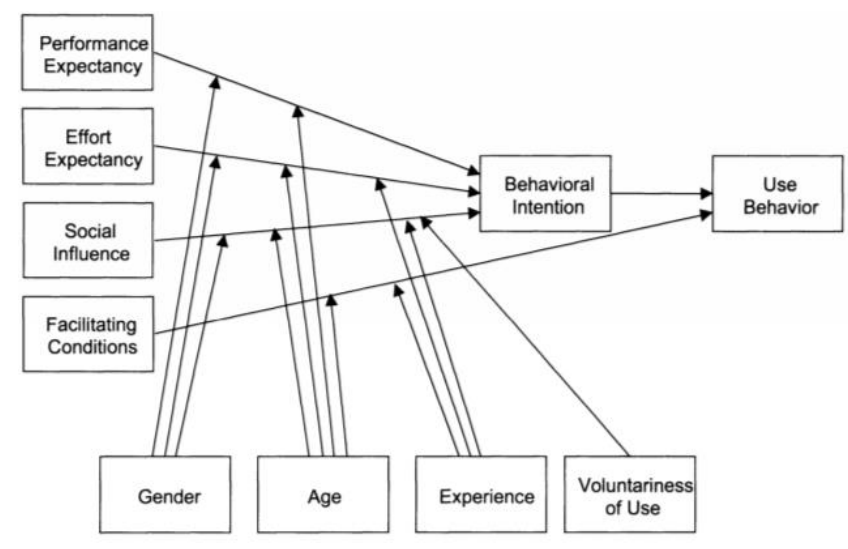

Gambar 3: Unified Theory of Acceptance and Use of Technology, UTAUT (Sumber: Venkatesh et al., 2003)

Perkembangan selanjutnya dari model TAM adalah TAM3, yang mengajukan tiga hubungan yang tidak diuji secara empiris di TAM2. Venkatesh dan Bala (2008) menambahkan bahwa pengalaman akan memoderasi hubungan antara: kemudahan penggunaan yang dirasakan dan kegunaan yang dirasakan; kecemasan komputer dan persepsi kemudahan penggunaan; dan persepsi kemudahan penggunaan dan niat perilaku.

Beberapa hasil penelitian yang telah dipublikasikan dengan menggunakan model TAM sebagai referensi untuk mendukung kebaruan riset ini adalah sebagai berikut: Rauniar, Rawski, Yang, Johnson (2013) meneliti tentang media sosial (Facebook) dengan keterbaruan pada terkait Critical mass, capability, dan perceived playfulness. Rahman \& Bakar (2019) meneliti tentang sistem registrasi, dengan keterbaruan pada adaptasi fitur desain. Tsai (2015) meneliti tentang Course Management System dengan keterbaruan tentang Technical support, user activities, Performance (learning outcomes). Koul \& Eydgahi (2018) meneliti tentang Driverless car technology dengan keterbaruan tentang years of experience dan age. Kalayou, Endehabtu, \& Tilahun (2020) meneliti tentang e-Health system dengan keterbaruan tentang IT experience dan technical infrastructure.

Pada penelitian ini, fokus penelitian adalah menganalisis keefektifan sistem seleksi dan registrasi mahasiswa baru, dengan keterbaruan riset adalah menggabungkan TAM dan UTAUT yang terkait dengan sistem seleksi dan registrasi mahasiswa baru, sehingga diperoleh model baru yang diberi nama TAM 
Agustinus Purna Irawan, Indra Widjaja:

Implementation of Technology Acceptance Model to Evaluate Reliability of the New Student Selection Application Development

Implementasi Technology Acceptance Model Untuk Mengevaluasi Keandalan Pengembangan Aplikasi Komunikasi Seleksi Mahasiswa Baru

API 2021. Model baru yang dikembangkan ini akan diuji coba untuk menganalisis proses seleksi dan registrasi mahasiswa baru yang dikembangkan di Universitas Tarumanagara dengan nama aplikasi adalah Go Untar. Hipotesis penelitian sebagai berikut:

H1: Perceived usefulness berpengaruh signifikan terhadap attitude toward using Go Untar

H2: Perceived ease of use berpengaruh signifikan terhadap attitude toward using Go Untar

H3: Social influence berpengaruh signifikan terhadap attitude toward using Go Untar

H4: Facilitating condition berpengaruh signifikan terhadap Go Untar Using Behavior

H5: Attitude toward using Go Untar berpengaruh signifikan terhadap Go Untar Using Behavior

H6a: Attitude toward using Go Untar menjadi mediasi yang signifikan pengaruh Perceived usefulness terhadap Go Untar Using Behavior

H6b: Attitude toward using Go Untar menjadi mediasi yang signifikan pengaruh Perceived ease of use terhadap Go Untar Using Behavior

H6c: Attitude toward using Go Untar menjadi mediasi yang signifikan pengaruh Social influence terhadap Go Untar Using Behavior

\section{Metode Penelitian}

Pada penelitian ini dilakukan kombinasi antara Model TAM Davis dan Model UTAUT untuk mendapatkan model baru yang dapat diimplementasikan untuk mengevaluasi keefektifan aplikasi Go Untar menjadi media komunikasi dan seleksi mahasiswa baru Universitas Tarumanagara. Model yang dikembangkan adalah sebagai berikut:

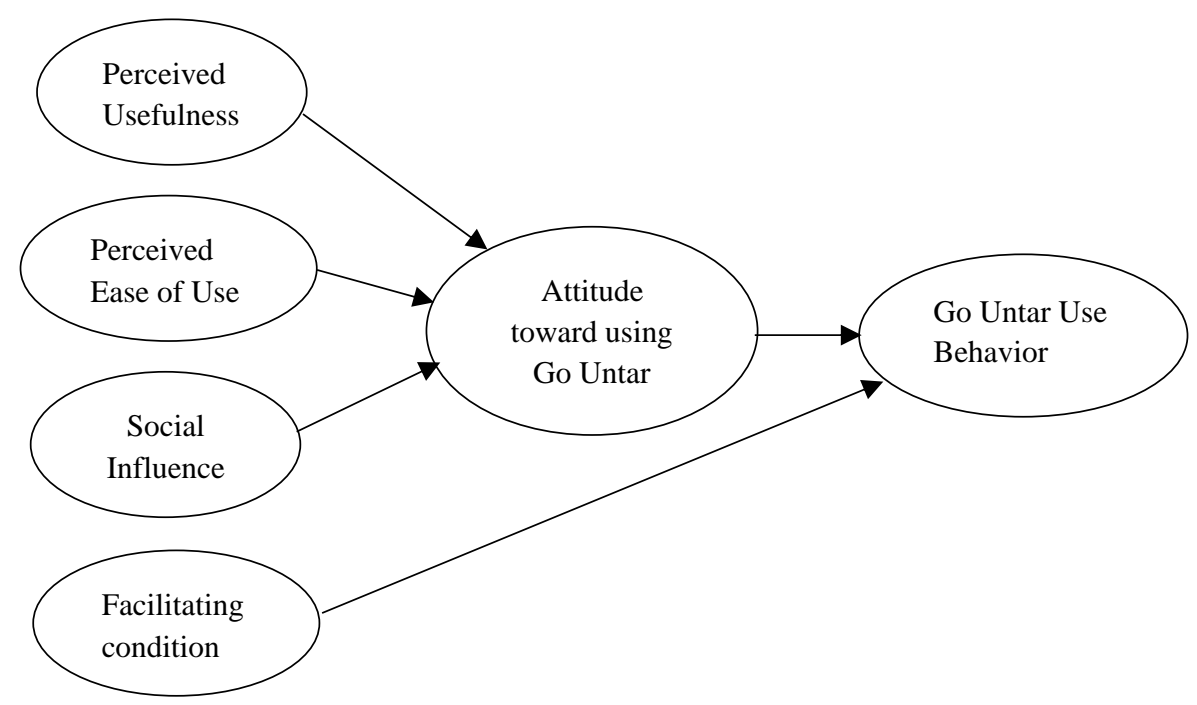

Gambar 4: Model Evaluasi Keefektifan Aplikasi Go Untar

(Sumber: Rancangan Peneliti) 
Untuk mengimplementasikan model seperti pada Gambar 4, disusun kuesioner dalam bentuk google form yang mudah diakses dan dipahami oleh mahasiswa baru untuk diisi. Selanjutnya kuesioner dibagikan kepada mahasiswa baru yang telah memanfaatkan aplikasi Go Untar sebagai media komunikasi dan seleksi mahasiswa baru Angkatan tahun 2021. Hasil kuesioner selanjutnya diolah dengan bantuan statistik dan dianalisis sesuai dengan temuan yang telah diperoleh dari para mahasiswa baru.

Metode sampel yang digunakan adalah purposive sampling, dengan kriteria: mahasiswa yang pernah menggunakan Go Untar, dalam kurun waktu sejak Juni 2020 sampai Juli 2021. Maka, tidak semua mahasiswa baru terpilih menjadi sampel, termasuk mahasiswa kedokteran karena diseleksi dengan menggunakan aplikasi tersendiri di luar Go Untar. Responden penelitian ini adalah mahasiswa baru Universitas Tarumanagara angkatan 2021 sebanyak 1769 orang. Berjenis kelamin relatif seimbang antara laki-laki dan perempuan (lebih banyak perempuan $=57 \%$ ), sebagian besar berusia antara 16-19 tahun, dan berasal dari 15 program studi di Untar, kecuali Fakultas Kedokteran. Pengambilan data 4 Agustus 2021.

Langkah kerja dalam melakukan analisis data yang telah diperoleh dari responden adalah sebagai berikut: menguji instrumen penelitian, untuk memastikan apakah kuesioner/indikator yang digunakan adalah tepat (evaluasi model pengukuran), menguji kesesuaian model (evaluasi model struktural), menguji hipotesis dan interpretasi, dan analisis deskriptif data, yang bertujuan untuk memahami respons responden terhadap Go Untar, dan dikaitkan dengan hasil pengujian hipotesis dapat memberikan implikasi manajerial.

Model penelitian seperti Gambar 5, diuji dengan bantuan statistik PLS-SEM

(Partial Least Squares Structural Equation Modelling), menggunakan program SmartPLS 3. Structural Equation Modeling merupakan metode analisis multivariat untuk menggambarkan hubungan linier secara simultan antara variabel pengamatan dan variabel yang tidak dapat diukur secara langsung. Partial Least Square merupakan teknik multivariat yang dapat digunakan untuk menganalisis variabel respon sampai variabel eksplanatori secara bersamaan.

\section{Hasil Penemuan dan Diskusi}

Penelitian ini bertujuan untuk mengembangkan model untuk mengevaluasi portal seleksi mahasiswa baru yang telah dikembangkan di Universitas Tarumanagara dengan nama Go Untar. Go Untar telah dikembangkan sejak tahun 2020 dan telah diimplementasikan untuk seleksi mahasiswa baru Angkatan 2020 seterusnya. Go Untar tidak saja menjadi wahana untuk seleksi mahasiswa baru, tetapi juga menjadi bagian penting sebagai media komunikasi yang intens dan efektif dengan calon mahasiswa baru. Dalam Go Untar, disediakan informasi terkait dengan program studi sarjana yang ada di Universitas Tarumanagara, sehingga calon mahasiswa dapat memilih program studi yang diinginkan. Komunikasi dua arah secara daring juga terjadi, secara khusus terkait dengan proses registrasi pembuatan akun, pengisian data, pelaksanaan seleksi, informasi hasil seleksi dan informasi biaya yang harus dibayarkan oleh calon mahasiswa yang diterima. Dalam hal ini, semua informasi yang dibutuhkan oleh calon mahasiswa dapat diakses 
Agustinus Purna Irawan, Indra Widjaja:

Implementation of Technology Acceptance Model to Evaluate Reliability of the New Student Selection Application Development

Implementasi Technology Acceptance Model Untuk Mengevaluasi Keandalan Pengembangan Aplikasi Komunikasi Seleksi Mahasiswa Baru

secara real time dan dapat diakses kapan saja. Go Untar juga dilengkapi dengan nomor kontak bagi yang membutuhkan bantuan jika mengalami kesulitan. Hal ini tentu sangat memudahkan calon mahasiswa untuk mendapatkan informasi yang dibutuhkan secara cepat dan akurat, baik secara daring maupun menggunakan nomor kontak pelayanan.

Berdasarkan data hasil kuesioner yang telah diisi oleh mahasiswa baru tahun 2021, langkah pertama adalah melakukan uji validitas dan reliabilitas yang bertujuan untuk memastikan bahwa semua indicator yang digunakan adalah tepat mengukur konstruk/variabelnya. Untuk itu dilakukan PLS-SEM Algorithm, yaitu melihat convergent validity and discriminant validity. Untuk convergent validity, dilihat dari outer loading yang menggambarkan korelasi setiap indikator dengan konstruksinya. Berdasarkan hasil uji menunjukkan bahwa loading factor semua indikator telah berada di atas 0,7, sehingga dapat dikatakan bahwa semua indikator valid dan dapat mengukur konstruknya. Sebelum tahapan ini penulis menghilangkan indicator Ease 10 dan Use6 karena faktor loadingnya di bawah 0,7. Untuk pengujian Discriminant Validity, penulis menggunakan kriteria Fornell and Larcker (1981 dalam Hair et al., 2014). Validitas diskriminan (discriminant validity) dapat tercapai saat akar kuadrat Average Variance Extracted (AVE) lebih besar dari korelasi antara variabel lain. Berdasarkan hasil uji menunjukkan nilai AVE semua variabel > 0,5 dan lebih besar dari korelasi variabel lain.

Uji reliabilitas menunjukkan bahwa semua variabel mempunyai Cronbach's Alpha > 0,7, yang berarti bahwa semua variabel telah reliabel, dapat diterima dengan sangat memuaskan (di atas 0,8 ). Pelaksanaan uji multikolinearitas bertujuan untuk menganalisis ada tidaknya korelasi antar variabel. Untuk mengetahui ada tidaknya multikolinearitas, maka yang perlu diperhatikan adalah nilai Variance Inflation Factor (VIF), dimana menurut Hair et al. (2012), "nilai VIF harus lebih kecil dari 5. Uji kolinearitas menunjukkan bahwa semua VIF < 5, yang berarti tidak terjadi kolinearitas. 


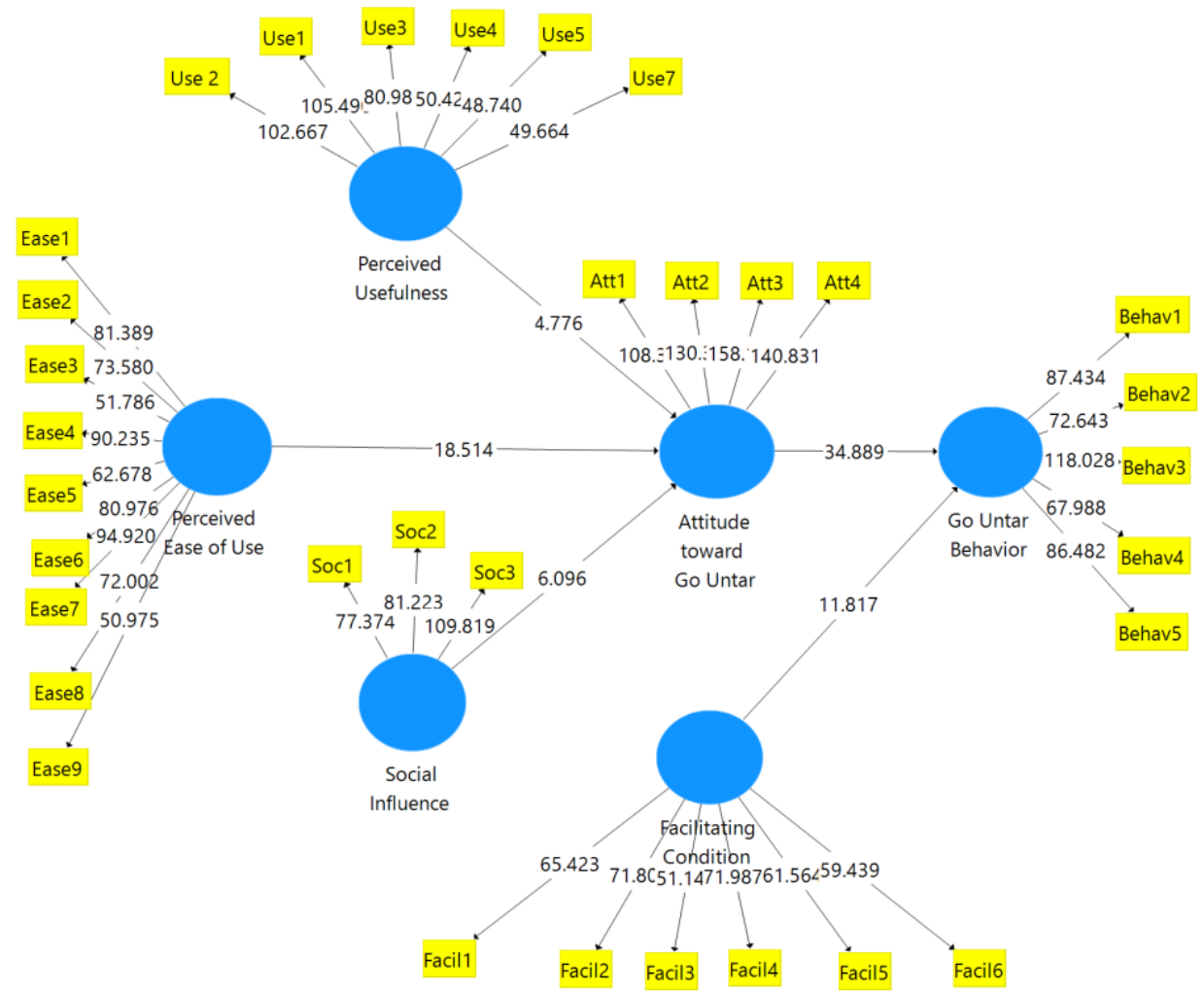

Gambar 7: Model (T value) Hasil Penelitian

Pada evaluasi inner model ini penulis menilai signifikansi hubungan antar konstruk/variabel. Sebelumnya dilakukan uji $\mathrm{R}^{2}$ dan Uji Goodness of Fit (GoF) untuk melakukan validasi model penelitian secara keseluruhan. $\mathrm{R}^{2}$ attitude toward Go Untar sebesar 0,668 mengindikasikan bahwa model pengaruh Perceived _Usefulness, Perceived_Usefulness, dan Social_Influence terhadap attitude toward Go Untar, baik (moderat). Begitu pula model pengaruh Attitude toward_Go Untar dan Facilitating Condition terhadap Go Untar using behavior baik, moderat $\left(\mathrm{R}^{2}=\right.$ 0,728).

Beberapa kriteria yang harus dipenuhi, agar model penelitian dianggap fit. Yang pertama, menurut Hu dan Bentler (1999), "nilai SRMR kurang dari 0.10 atau kurang dari 0.08, dianggap good fit." Kemudian, terkait nilai Exact Model Fit, dengan menggunakan Convidence Interval 95\%, maka nilai d_ULS dan d_G lebih kecil dari 0.95 masuk ke dalam kategori "good fit". Selanjutnya, nilai Normed Fit Index (NFI) berada di antara 0 sampai 1, makin mendekati 1 makin baik, dan jika nilai di atas 0.9 umumnya dianggap "acceptable fit". Untuk nilai Chi-Square (X2), dibagi dengan degree of freedom $(d f)$ harus di bawah 5, untuk dianggap "good fit". Adapun rumus degree of freedom $(d f)=\mathrm{n}-\mathrm{k}-1=1738-6-1=1731$. Henseler et al. (2014) mengatakan bahwa jika nilai $R M S$ _theta lebih kecil sama dengan 0.12, maka mengindikasikan model well-fit. Berdasarkan hasil pengujian diperoleh bahwa sebagian besar ukuran GoF menghasilkan good fit, dengan demikian maka secara keseluruhan model penelitian ini baik. 
Agustinus Purna Irawan, Indra Widjaja:

Implementation of Technology Acceptance Model to Evaluate Reliability of the New Student Selection Application Development

Implementasi Technology Acceptance Model Untuk Mengevaluasi Keandalan Pengembangan Aplikasi Komunikasi Seleksi Mahasiswa Baru

Setelah memastikan bahwa semua indikator valid, semua variabel reliabel, dan model penelitian memenuhi goodness of fit (baik), maka selanjutnya diambil keputusan mengenai hipotesis (Tabel 1) dengan melihat koefisien jalur (path coefficient) dan indirect effect. Pada pengujian model structural terlihat bahwa Perceived _Usefulness berpengaruh positif signifikan terhadap Attitude toward _Go Untar ( $\mathrm{t}=4,776 \mathrm{p}=0,000)$, dengan demikian hipotesis 1 diterima. Perceived_Ease of Use berpengaruh positif dan signifikan terhadap Attitude toward _Go Untar $(\mathrm{t}=18,514 \mathrm{p}=0,000)$, maka hipotesis 2 diterima. Social_Influence berpengaruh positif dan signifikan terhadap Attitude toward_Go Untar ( $\mathrm{t}=18,514$ $\mathrm{p}=0,000$ ), maka hipotesis 3 diterima. Attitude toward_Go Untar berpengaruh positif dan signifikan terhadap Go Untar using Behavior $(\mathrm{t}=34,889 \mathrm{p}=0,000)$, hipotesis 5 diterima. Begitu pula Facilitating Condition berpengaruh positif dan signifikan terhadap Go Untar using Behavior $(\mathrm{t}=11,817 \mathrm{p}=0,000)$, hipotesis 4 diterima.

Variabel yang mempunyai pengaruh terbesar terhadap attitude toward Go Untar adalah perceived ease of use $\left(\mathrm{f}^{2}=0,406\right)$. Cohen (1988 dalam Hair et al., 2014) mengatakan bahwa 0.02, 0.15, and 0.35 merepresentasikan small, medium, and large effects. Hal ini menunjukan bahwa efek perceived ease of use terhadap attitude toward Go Untar termasuk dalam kategori efek besar. Selanjutnya attitude toward Go Untar ini memiliki efek yang besar terhadap Go Untar behavior $\left(\mathrm{f}^{2}=0,863\right)$.

Tabel 1: Model Struktural dan Keputusan Hipotesis

\begin{tabular}{lccl}
\hline & $\begin{array}{c}\text { T } \\
\text { Statistics }\end{array}$ & P Values & Keputusan \\
\hline $\begin{array}{l}\text { Attitude toward_Go Untar -> Go } \\
\text { Untar_Behavior }\end{array}$ & 34,889 & 0,000 & $\begin{array}{l}\text { Hipotesis 5 } \\
\text { diterima }\end{array}$ \\
\hline Facilitating Condition -> Go Untar_Behavior & 11,817 & 0,000 & $\begin{array}{l}\text { Hipotesis 4 } \\
\text { diterima }\end{array}$ \\
\hline $\begin{array}{l}\text { Perceived_Usefulness -> Attitude toward_Go } \\
\text { Untar }\end{array}$ & 4,776 & 0,000 & $\begin{array}{l}\text { Hipotesis 1 } \\
\text { diterima }\end{array}$ \\
\hline $\begin{array}{l}\text { Perceived_Ease of Use -> Attitude toward_Go } \\
\text { Untar }\end{array}$ & 18,514 & 0,000 & $\begin{array}{l}\text { Hipotesis 2 } \\
\text { diterima }\end{array}$ \\
\hline Social_Influence -> Attitude toward_Go Untar & 6,096 & 0,000 & $\begin{array}{l}\text { Hipotesis 3 } \\
\text { diterima }\end{array}$ \\
\hline
\end{tabular}




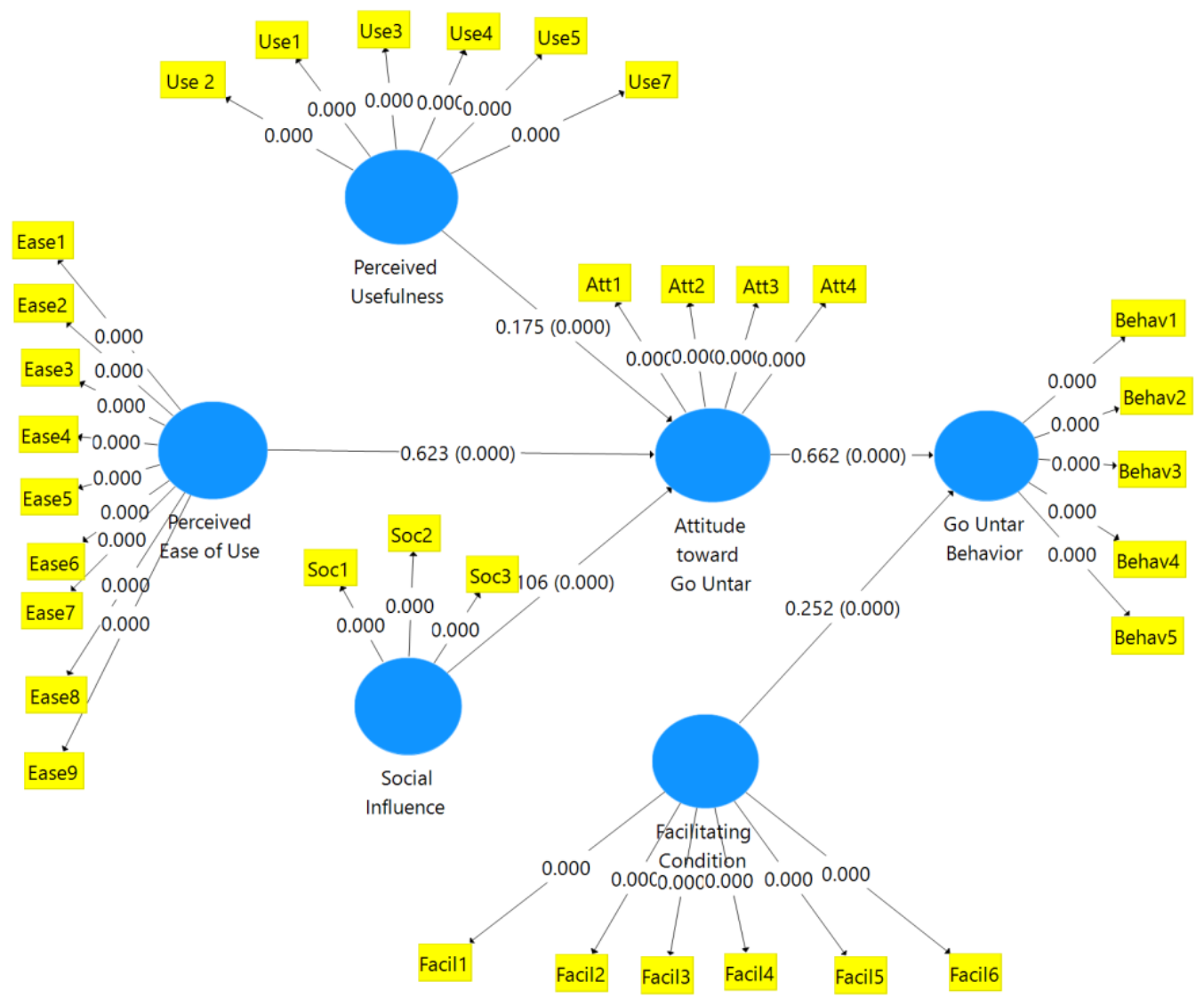

Gambar 8: Path Coefficient dan p value

Pada pengujian indirect effect menunjukkan bahwa ketiga jalur yang melalui attitude toward Go Untar sebagai mediasi, signifikan. Attitude toward Go Untar menjadi mediasi yang signifikan pada pengaruh perceived usefulness terhadap Go Untar using behavior $(\mathrm{t}=4,632 \mathrm{p}=0,000)$. Attitude toward Go Untar menjadi mediasi yang signifikan pada pengaruh perceived ease of use terhadap Go Untar using behavior ( $\mathrm{t}=16,664 \mathrm{p}=0,000)$. Demikian pula Attitude toward Go Untar menjadi mediasi yang signifikan pada pengaruh social influence terhadap Go Untar using behavior $(\mathrm{t}=6,008 \mathrm{p}=0,000)$. Dengan demikian, hipotesis $6 \mathrm{a}, 6 \mathrm{~b}$, dan $6 \mathrm{c}$ diterima.

Hipotesis 1, 2, dan 3 penelitian ini didukung data (diterima), hal ini berarti bahwa Go Untar sebagai aplikasi pendaftaran mahasiswa baru dipersepsikan oleh responden (mahasiswa baru Angkatan 2021) sebagai aplikasi yang memiliki performa yang baik untuk melakukan pendaftaran, mudah digunakan, dan orangorang di sekitar mahasiswa (orang tua, saudara, teman) mendukung responden untuk menggunakan Go Untar. Ketiga hal tersebut (kegunaan, kemudahan, dan dukungan sosial) membuat mahasiswa memiliki sikap (attitude) yang positif dalam menggunakan Go Untar. Selanjutnya sikap yang positif ini membuat mahasiswa berperilaku positif juga dalam menggunakan Go Untar, yaitu dapat menggunakan dengan cepat, mendapat hasil akurat, dan merekomendasikan Go Untar pada orang lain. Diterimanya Hipotesis 4 menunjukkan bahwa penggunaan Go Untar didukung oleh kemampuan mahasiswa menggunakan aplikasi dan fasilitas pendukung dari 
Agustinus Purna Irawan, Indra Widjaja:

Implementation of Technology Acceptance Model to Evaluate Reliability of the New Student Selection Application Development

Implementasi Technology Acceptance Model Untuk Mengevaluasi Keandalan Pengembangan Aplikasi Komunikasi Seleksi Mahasiswa Baru

Untar (tersedianya bimbingan, instruksi, dan tim khusus yang membantu), yang kedua hal ini membuat mahasiswa dapat menggunakan Go Untar dengan cepat, merasakan manfaat Go Untar dan merekomendasikannya pada orang lain (positive behavior).

Sikap mahasiswa terhadap menggunakan Go Untar (attitude toward using Go Untar) terbukti dapat menjadi mediasi yang signifikan (Hipotesis 6a, 6b, 6c), menandakan bahwa kegunaan, kemudahan, dukungan orang sekitar mampu membuat mahasiswa mempersepsikan bahwa Go Untar sebagai positif (baik), dan hal ini membuat mereka dapat menggunakan Go Untar dengan baik.

Tabel 2: Indirect Effect dan Keputusan Hipotesis

\begin{tabular}{lrrl}
\hline & T Statistics & P Values & \multicolumn{1}{c}{ Keputusan } \\
\hline $\begin{array}{l}\text { Perceived_Usefulness -> Attitude toward } \\
\text { _Go Untar -> Go Untar_Behavior }\end{array}$ & 4,632 & 0,000 & $\begin{array}{l}\text { Hipotesis 6a } \\
\text { diterima }\end{array}$ \\
\hline $\begin{array}{l}\text { Perceived_Ease of Use -> Attitude toward } \\
\text { Go Untar -> Go Untar_Behavior }\end{array}$ & 16,664 & 0,000 & $\begin{array}{l}\text { Hipotesis 6b } \\
\text { diterima }\end{array}$ \\
\hline $\begin{array}{l}\text { Social_Influence -> Attitude toward_Go } \\
\text { Untar -> Go Untar_Behavior }\end{array}$ & 6,008 & 0,000 & $\begin{array}{l}\text { Hipotesis 6c } \\
\text { diterima }\end{array}$ \\
\hline
\end{tabular}

Berdasarkan hasil penelitian ini terlihat bahwa Go Untar sebagai media komunikasi dan seleksi mahasiswa baru, telah berjalan dengan baik dan efektif. Komunikasi yang dibangun antara pengelola seleksi mahasiswa baru dalam hal ini kantor admisi dengan calon mahasiswa baru, telah berjalan dengan baik, dan semuanya dilaksakanakan secara daring. Komunikasi yang baik dengan calon mahasiswa dan semua mahasiswa aktif, akan meningkatkan kepuasan dan kepercayaan kepada perguruan tinggi. Pengiriman informasi terkait dengan seleksi mahasiswa baru, program pembelajaran dan kegiatan administrasi lainnya, menjadi bagian penting dari layanan kepada semua pemangku kepentingan. Makin intens komunikasi yang dilakukan dan kebutuhan informasi terpenuhi dengan cepat dan berkualitas, maka akan berdampak positif bagi keberlanjutan suatu perguruan tinggi dalam menjalankan misinya di dunia pendidikan (Al-Khasawneh \& Bakir, 2019).

\section{Simpulan}

Berdasarkan hasil penelitian yang telah dilakukan dengan menggunakan model TAM yang dimodifikasi, dapat disimpulkan sebagai berikut: model yang dikembangkan dalam penelitian ini yaitu model TAM API 2021 yang merupakan model gabungan TAM dan UTAUT (terkait dengan sistem registrasi), telah divalidasi dan dapat digunakan untuk menganalisis keefektifan dan kemudahana Go Untar dalam proses seleksi mahasiswa baru. Go Untar dipersepsikan bermanfaat untuk melakukan registrasi dengan cepat, efektif, dan dapat melihat hasil yang akurat. Go Untar mudah, jelas, dapat dimengerti, tidak perlu usaha mental, mudah diakses, mudah mendaftar di prodi yang dituju, dan mudah untuk memperoleh hasil seleksi. Proses seleksi menggunakan Go Untar memberikan pengalaman kemudahan dan kelancaran dalam proses seleksi yang cepat, mudah dan sesuai dengan kebutuhan calon mahasiswa. Go Untar menjadi satu-satunya sistem penerimaan mahasiswa baru yang dapat diandalkan dan tidak membutuhkan 
bantuan admin selama calon mahasiswa melakukan proses seleksi. Go Untar menjadi media komunikasi yang efektif bagi calon mahasiswa baru dengan pengelola dan berbagi informasi terkait dengan seleksi mahasiswa baru. Komunikasi yang berkualitas berdampak positif terhadap kepuasan pemangku semua kepentingan dan dapat menjadi salah satu media dalam membangun reputasi perguruan tinggi.

\section{Daftar Pustaka}

Al-Khasawneh, A. L., \& Bakir, S. H. A. (2019). The Influence of Communication Process Elements on Students Satisfaction: Field Study on Jordanian Private Universities. European Journal of Economics, Finance and Administrative Sciences, 100, 7-23.

Alharbi, S. (2014). Using the Technology Acceptance Model in Understanding Academics' Behavioural Intention to Use Learning Management Systems. International Journal of Advanced Computer Science and Applications, $143-155$.

Chuttur, M. (2009). Overview of the Technology Acceptance Model: Origins, Spouts. Working Papers on Information Systems, 9-37.

Davis, F. . (1985). A Technology Acceptance Model for Empirically Testing New End-User Information Systems: Theory and Results. Massachusetts Institute of Technology.

Davis, F. . (1989). Perceived Usefulness, Perceived Ease of Use dan Acceptance of Information System Technology. MIS Quartery, 13(3), 319-339.

Dyatmika, T. (2018). Strategi Komunikasi Penerimaan Mahasiswa Baru Di Universitas Muhammadiyah Cirebon. SOSFILKOM: Jurnal Sosial, Filsafat Dan Komunikasi, 12(2), 36-50.

Fornell, C., \& Larcker, D. . (1981). Evaluating Structural Equation Models with Unobservable Variables and Measurement Error. Journal of Marketing Research, 18(1), 39-50.

Hair, J. F. J., Hult, G. T. M., Ringle, C. M., \& Sarstedt, M. (2014). A Primer on Partial Least Squares Structural Equation Modeling (PLS-SEM). SAGE Publications, Inc.

Hair, J. F. J., Sarstedt, M., \& Ringle, C. . (2012). An assessment of the use of partial least squares structural equation modeling in marketing research. Journal of the Academy of Marketing Science, 40(3), 414-433.

Harjadi, D., \& Fatmasari, D. (2017). Implementation of Integrated Marketing Communication in Image of Private Higher Education. Trikonomika, 16(2), 63-67.

Henseler, J., Dijkstra, T. ., Sarstedt, M., Ringle, C. ., Diamantopoulos, A., Straub, D. ., Ketchen, D. J. J., Hair, J. ., Hult, G. T. ., \& Calantone, R. . (2014). Common beliefs and reality about PLS: comments on Rönkkö \& Evermann (2013). Organizational Research Methods, 17(2), 182-209.

Hu, L., \& Bentler, P. M. (1999). Cutoff criteria for fit indexes in covariance structure analysis: Conventional criteria versus new alternatives. Structural Equation Modeling, 6(1), 1-55. 
Agustinus Purna Irawan, Indra Widjaja:

Implementation of Technology Acceptance Model to Evaluate Reliability of the New Student Selection Application Development

Implementasi Technology Acceptance Model Untuk Mengevaluasi Keandalan Pengembangan Aplikasi Komunikasi Seleksi Mahasiswa Baru

Kalayou, M. H., Endehabtu, B. F., \& Tilahun, B. (2020). The Applicability of the Modified Technology Acceptance Model (TAM) on the Sustainable Adoption of eHealth Systems in Resource-Limited Settings. Journal of Multidisciplinary Healthcare, 2020:3, 1827-1837.

Koul, S., \& Eydgahi, A. (2018). Utilizing Technology Acceptance Model (TAM) for driverless car technology. Journal of Technology Management \& Innovation, 13(4), 37-46.

Ongvongphaiboon, P., \& Chantamas, M. (2021). No Titlenfluence of digital marketing communication and performance effectiveness between $\mathrm{b} 2 \mathrm{~b}$ companies and clients in Thailand. Utopía y Praxis Latinoamericana, 26(2), $171-182$.

Peratuaran Menteri Pendidikam dan Kebudayaan Republik Indonesia Nomor 3 Tahun 2020, (2020). https://jdih.kemdikbud.go.id/arsip/Salinan PERMENDIKBUD 3 TAHUN 2020 FIX GAB.pdf

Rahman, T. F. A., \& Bakar, Z. A. (2019). Exploring Users' Perspectives on CoCurricular Registration System using TAM Model. Journal of Advanced Research in Computing and Applications, 16(1), 24-33.

Rauniar, R., Rawski, G., Johnson, B., \& Yang, J. (2013). Social Media User Satisfaction-Theory Development and Research Findings. Journal of Internet Commerce, 12, 195-224.

Tsai, Y.-R. (2015). Applying the Technology Acceptance Model (TAM) to explore the effects of a Course Management System (CMS)-Assisted EFL writing instruction. CALICO Journal, 32(1), 153-171.

Venkatesh, V., \& Bala, H. (2008). Technology Acceptance Model 3 and a Research Agenda on Interventions. Decision Sciences, 39(2), 273-315.

Venkatesh, V., \& Davis, F. . (2000). A Theoretical Extension of the Technology Acceptance Model: Four Longitudinal Field Studies. Management Science, 46(2), 186-204.

Venkatesh, V., Morris, M. G., Davis, G. B., \& Davis, F. D. (2003). User Acceptance of Information Technology: Toward a Unified View. MIS Quarterly, 27(3), $425-478$. 